\title{
Internal Security, Management of Funds and IPPIS Challenges among Unions and Cooperative Societies in Tertiary Institutions in Nigeria
}

\author{
Princewill Egwuasi, Emem E. Umoren, Husseina K. Wakili, Rebecca J. Akpabio
}

\begin{abstract}
The constant outcry of misuse and mismanagement of funds in governmental organisations have given concern to several researches, debates and blame games. Our focus in this qualitative study is to interpretively examine the extent of internal security and management measures that are explorable in curtailing the inability to recover dues and third party loans in an IPPIS challenge-prone era among unions and cooperative societies in tertiary institutions in Nigeria, the University of Uyo, Uyo being our focus point. The study is an interpretive research that employed semi-structured interviews for the chairpersons of ASUU, SSANU, NASU and NAAT and the presidents of cooperative societies run by the unions in a federal university such as ours. These chairpersons and presidents were purposively selected for the study. Three research questions were raised to guide the study: What internal security measures are put in place by the unions to ensure recovery of dues and third party loans from debtors? How do the cooperative societies manage their funds and recover dues and third party loans during the IPPIS era? What relationship exists between the unions, cooperative societies and IPPIS office for dues and third party loans recovery? The findings of the study showed that there is no full proof of internal security measures put in place to recover dues and third party loans; that committees are set up in the cooperative societies to manage their funds through several management strategies; there is no clear relationship between the Unions, cooperative societies and IPPIS Office to aid in the recovery of dues and third party loans in the university. The study recommended among others that the IPPIS should be transparent enough to abide by the laws of its establishment in order not to under mind its primary functions of deduction and remittance of dues and third party loans to beneficiaries.
\end{abstract}

Keywords: Internal Security, Mismanagement, Funds, IPPIS, Unions, Tertiary Institutions.

\section{INTRODUCTION}

The university system, the world over, is an indispensable, highly structured enclave, with complex formal and informal groups, that work together for the realization of the short and long term objectives for its establishment.

\footnotetext{
Manuscript received on 23 March 2021 | Revised Manuscript received on 14 June 2021 | Manuscript Accepted on 15 October 2021 | Manuscript published on 30 October 2021.

* Correspondence Author

Princewill I. Egwuasi*, Department of Curriculum Studies, Educational Management and Planning, University of Uyo, Uyo, Nigeria.

Emem E. Umoren, Department of Curriculum Studies, Educational Management and Planning, University of Uyo, Uyo, Nigeria.

Husseina K. Wakili, Department of Curriculum Studies, Educationa Management and Planning, University of Uyo, Uyo, Nigeria.

Rebecca J. Akpabio, Department of Curriculum Studies, Educational Management and Planning, University of Uyo, Uyo, Nigeria.

(C) The Authors. Published by Lattice Science Publication (LSP). This is an open access article under the CC-BY-NC-ND license (http://creativecommons.org/licenses/by-nc-nd/4.0/)
}

Among these groups are the unions, otherwise known as pressure groups, labour unions or trade unions. They are usually not in the consideration of the day-to-day administration of the university, but by nature of their importance, composition and functions, no meaningful achievement can be recorded without concrete administrative relationship with them.

Unionism is as old as mankind, hence, it has always been an instrument that the workforce employ to press home their needs, aspirations and innovative creativities towards the betterment of their staff members and that of their mother organisations at large. A union can be seen as the coming together of individuals, within an organizational structure, who are like minds, to proffer solutions and better welfare for its registered members.

Orji and Ringim (2016) see them as labour unions, which is an organization of workers who have banded together to achieve common goals such as protecting the integrity of its trade, achieving high pay, increasing the number of employees an employer hires and better working conditions. Based on these, the unions have continuously become a force to reckon with, especially in the Nigerian universities (Abdullahi, 2001).

Notable among them in Nigerian universities are:

- $\quad$ The Academic Staff Union of Universities (ASUU)

- $\quad$ The Senior Staff Union of Nigerian Universities (SANUU)

- $\quad$ The Non-Academic Staff Union (NASU)

- National Association of Academic Technologists (NAAT)

These unions, according to Etim and Egwuasi (2007), are founded on the concept and belief that unionism and professionalism are intricately intertwined, which means that the unions are driven by goals, concepts and ideas. They are noted to collectively provide a platform in the development of their mother institutions by complimenting in the provision of learning facilities and conditions of service, raise fallen standard of education and the financial base of the universities through the creation, establishment and administration of cooperative societies.

To this end, cooperative societies are business ventures, with the sole aim of profit-making and enhancement of the wellbeing of its members. However, Effiom (2014) argues that though cooperative societies are business organisations, they are formed based on certain principles which distinguishes them from other business organisations. From our viewpoint, these include:

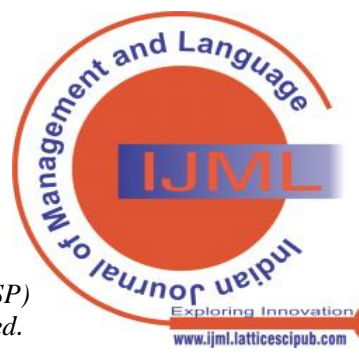


- $\quad$ Mutual understanding by all members of the modus operandi of the organization.

- Thrift savings, which is compulsory for all members.

- $\quad$ Risks are borne by all members.

- $\quad$ Profits are enjoyed by all members depending on the level of investment of each member.

- Low, reduced and controlled prices of goods and services to members.

- Issuance of loans to members at highly reduced interest rates.

- Acquiring of properties and sale to members on hire purchase policy, among other things.

Buttressing further, Odey (2009) in Effiom (2014)

posited that the principles may also be based upon the new models of scientific management of businesses and applied economics. To this end, Effiom (2014) highlights the principles along the path of democratic lines, where members have equal rights of voting and being voted for, equal opportunity to participate in the management and control of the societies and make inputs to policies.

In another development, cooperative societies are selfhelp organisations, which are formed with the aim of helping themselves solve their economic problems and thereby achieving a degree of self-reliance through joint and mutual action or aid (Asuquo, 2016). The philosophy of cooperative societies is to serve the common man and liberate him from the oppression of the economically strong people and other organisations. It is also seen as an enterprise ordinarily set up by the economically weak individuals to further their common economic and social interest, to eradicate capitalism, exploitation, eliminate middlemen and to bring the consumer and the producer together (iEduNote, 2017).

Regrettably, instead of continuous positive recognition, appreciation and commendations about the ingenuity, legality, administration and the intended aims of their formation, the cooperative societies, especially in the University of Uyo, have come under very serious criticisms, dishonesty and disapproval from the cooperators and the university management in general, as regards management of the funds of the individual cooperators, occasioned by the societies inability to recover loans, payment of thrift savings to beneficiaries and completion of various projects. This is even more worrisome, alarming and disturbing with the Federal Government of Nigeria's recent introduction of the Integrated Payroll and Personnel Information System (IPPIS), where the system makes it very difficult for cooperatives to assess funds from cooperators to offset all financial indebtedness.

It is against this unfortunate and ugly trend that this paper comes on board; to determine, among other things, internal security, management of funds and IPPIS challenges among unions and cooperative societies in tertiary institutions in Nigeria, a case for which the University of Uyo, Uyo, Nigeria is our focus.

\section{Statement of the Problem}

The constant outcry of misuse, mismanagement and misappropriation of funds in governmental organisations such as the university institutions, have given concern to several insightful investigations, blame games and faultfindings in different fora. Even when the larger government officials may be seen as corrupt personnel, with unaccountable attitude to funds entrusted in them. What has led to several cases of litigations among staff and cooperators of cooperative societies in the universities, including the University of Uyo, Uyo.

The University of Uyo at one time or the other had been thrown into chaos, free-for-all fight, destruction of properties and near-loss of lives, evidenced by how several union leaders and that of the cooperative societies have mismanaged the funds of their members. In other situations, these had led to the dragging of the university management into embarrassment. Our observations are that all these boil down to the union and that of the cooperative societies' leadership inability to recover loans and other financial assistance to members, which has led to a general reduction in all staff salaries, suspension of some staff members and distrust to the leadership.

This unwanted situation has suddenly resurfaced, where salaries are deducted indiscriminately, loans not recovered, cooperators and university staff not being sincere enough to personally remit their financial obligations to the various unions and the cooperative societies since the introduction of IPPIS. This is the problem of this study; how would the unions, university bursary and IPPIS office synergise to resolve this clog in the wheel of progress of university staff especially as it has to do with loans recovery.

\section{REVIEW OF RELATED LITERATURE}

\section{Theoretical Framework}

The techniques used in debt recovery are about the relationship that is present between the institution (cooperative societies) that lends and the borrower (cooperators/staff members) of funds (Kamar and Ayuma, 2016). The scholars were of the further stance that there should be a mutual benefit that accrues to both the lender and the borrower when the debt is fully collected. However, the lender gains profit from the scope between lending rate and interest on deposit rate. Kamar and Ayuma (2016) also stated that the borrower should be assured of a favourable account transactions score from the lender upon full payment of debts. To this end, the authors posited that the best theory in debt recovery is the Expected Utility Theory.

\section{John Von Neumann, Oskar Morgenstern Expected Utility Theory}

The Expected Utility Theory deals with the analysis of situations where individuals must make decisions without knowing which outcomes may result from that decision, that is, decision made under uncertainty. The most important aspect of this theory is that, the individuals are usually faced with the issue of having to contend with limited information, that would show a systematic bias in the processing of that same information. Kamar and Ayuma (2016) conclude that in this regard, it holds that behaviours like default on debt repayment are motivated by risk aversion with an expected utility of unwarranted gains through earnings from the unpaid debts.

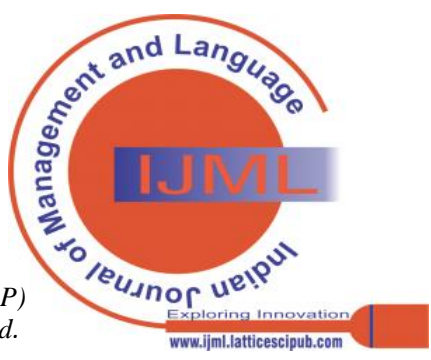


Based on this premise, Elesas and Associates (1998) suggested that collecting reliable information from potential borrowers becomes significant in achieving effective screening in debt recovery techniques that are used to enhance performance of financial institutions as suggested by Expected Utility Theory.

The relevance of this theory to the present study is that, the knowledge of the theory would avail the participants, that is, the unions, cooperative societies and the university staff cooperators, the need to acquire all the necessary information that would aid in loan recovery in the case of default in repayment of such loans.

\section{Adam Smith Agency Theory of 1937}

Another theory that supports the present study is the Agency Theory of Adam Smith. This theory simply describes the relationship between the various interested parties in an organization. Agency Theory further captures the duties and conflicts that usually occur between parties who have what is known as agency relationship. This relationship exists when one party (Principal) employs another party (agent) to perform a task on behalf of the employer. To this end, the theory explains the action of the various interest groups in the corporate governance debate.

The relevance of this theory to the present study is that the knowledge of this theory will guide the unions, cooperative societies, the bursary department and the IPPIS office to know that there must be a mutual administrative relationship, duties well stated and conflicts resolved, as interested parties in the university organization towards the recovery of loans from the university staff cooperators.

\section{CONCEPTUAL FRAMEWORK}

\section{Internal Security and Recovery of Loans}

Security is a necessity that must be put in place by any organizational management in other to achieve peace, order and success. It entails strategies and measures, both physical and administrative policies and measures, stipulated for strict adherence. Internally within the university system, Business Victoria (2019) outlined some of the internal security measures for loan recovery to include:

- $\quad$ To contact the borrowers with a friendly payment reminder.

- To contact the borrowers with an overdue payment reminder.

- $\quad$ To contact the borrowers with a final notice.

- $\quad$ To make direct contact with the borrowers

- $\quad$ To send a formal letter of demand.

- $\quad$ To use a debt collecting agency as a last resort.

In another development, Kamar and Ayuma (2016) posited that while safeguarding the relationship between parties of interest in the loan recovery, the internal security could be in the area of:

- Account transactions

- Guarantors

- Auction

- Collateral retention

The account transactions measure is to ensure and make an illustration of the deposits and expenses of the account of the potential borrowers. Guarantors are persons who would pay the loans in the eventuality that the borrower becomes incapable of payment of the loans acquired. Auction, on the other hand, is the buying and selling of properties, goods and services, through presenting them for due bid, receiving bids and then selling the goods to bidders who bid the highest, in the event to recover loans from a defaulting borrower. Collateral here means the form of property or assets (landed) assured and put forward as a security for a loan.

\section{Management of Funds and Loan Recovery}

The concept of management is highly understood differently, according to the context of usage. Here, we see management as the proper accountability of resources at the disposal of an individual. Collaborating our stance, Hissom (2009) stated that management is the organizational process that includes strategic planning, setting objectives, managing resources, deploying the human and financial assets needed to achieve the objectives, and measuring results. According to Hissom, the most important aspect of management is that it also includes recording and storing facts and information for later use for others within the organization. The importance of this being that management is the juggling of resources, including money, supplies and personnel.

As regards loan recoveries, Francis (2010) posited that the information on debt recovery policy and code of conduct in recovery process should be made available to the borrowers at the loan initiating stage. To this end, Fortunate (2011) in his study on credit policy management and loan recovery process in the banking sector: a case study of postbank Uganda (Kabule Branch), found out among other things that the recovery procedures are significant in the success of loan recoveries. The study concluded that these procedures included seeking for security, loan follow-up and monitoring and client screening to find the credit worthiness of the loan applicant.

\section{Integrated Personnel and Payroll Information System (IPPIS) and Loan Recovery}

The Integrated Personnel and Payroll Information System, popularly known as IPPIS, is a newly introduced payment system of salaries and other workers' entitlements in all federal government establishments, including the Nigerian universities. The most important reason for the implementation of the system, is to eliminate ghost workers. Furthermore, IPPIS was also designed to capture facial images, finger prints of the government employees and store them in a digital database library, which at any point in time can be assessed and used.

In their submissions, Ikeanyionwu and Ugochukwu (2020) informed that the IPPIS secretariat is a department domiciled at the office of the Accountant-General of the Federation, responsible for payment of salaries and wages directly to government employees bank accounts with appropriate deductions and remittances of third parties such as Federal Inland Revenue Service, State Boards of Internal Revenue, National Health Insurance Scheme, National Housing Fund, Pension Fund Administration, Cooperative Societies, Trade Unions Dues, Association Dues and Bank Loans.

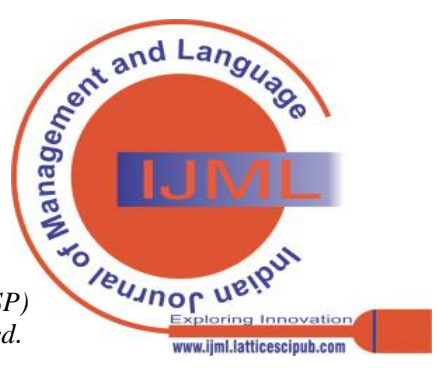


Though, there are very scanty literature on how the system has helped in the recovery of loans in the universities, especially the University of Uyo, Uyo, Nigeria, the current researchers' observations have been that its in the University of Uyo, as there are shortages in salaries, deductions without explanations and most importantly, nonremittance of third parties dues, swift savings and loans recovery.

\section{Research Questions}

We set out on a profound investigation of internal security, management of funds and IPPIS challenges among unions and cooperative societies in tertiary institutions in Nigeria, with a focus on the University of Uyo, Uyo, Nigeria, guided by three research questions.

1) What internal security measures are put in place by the unions and the cooperative societies to ensure recovery of dues and third party loans from debtors?

2) How do the cooperative societies manage their funds and recover dues and third party loans during the IPPIS era?

3) What relationship exists between the unions, third party loans recovery?

\section{METHODOLOGY AND ETHICAL CONSIDERATIONS}

In order to explore participants' perspective and actions through conceptual terms of internal security, management of funds and IPPIS, we followed the tradition of interpretive research. Being a qualitative approach, emphases are on the qualities of entities, process and meanings that are not experimentally examined or measured in terms of quantity and amount of frequency (Denzin and Licolin, 2000).

Through semi-structured interviews, we worked to understand the contending issues from the participants' points of view, to unfold meaning of peoples' experiences. To gather a breath of contextual information about the issues at hand, we gave each participant thirty minutes to provide vivid answers to asked questions. To this end, adequate ethical considerations were ensured that detrimental and character assassinations were prevented while ensuring that truthful responses only were derived. We employed Lincoln and Guba (2011)'s norms of trustworthiness namely: credibility, transferability and conformity to promote confidence that the researchers recorded accurately the phenomena under investigations.

Only the presidents of the three cooperative societies in the university and the four union chairmen were interviewed. This is because the cooperatives, that is, UNIUYO Multipurpose Cooperative Society, UNIUYO Academic Cooperative Society (UNAMCOOPS) and Senior Staff Multipurpose Cooperative Society are managed by all the four unions, ASUU and SSANU respectively. The study is carried out in the 2019/2020 academic session during the corona virus pandemic and ASUU strike with the Federal Government of Nigeria. The university was under lock and keys, but the cooperative societies and unions were operational. implementation has brought more corruption, controversies and challenges among the unions and cooperative societies cooperative societies and IPPIS office for dues and

\section{Findings of the Study}

As at the time of the interview, only four out of all the participants were available. They were marked as participants A, B, C and D respectively.

\section{Research Question 1}

What internal security measures are put in place by the unions and cooperative societies to ensure recovery of loans from debtors?

\section{Responses}

The responses were got from the chairpersons and one president of the cooperative societies are recorded below:

\section{Chairman A:}

"There is no full proof mechanism to aid cooperative societies recover loans from debtors".

\section{Chairman B:}

"The mechanism is simply to sensitize the members and debtors to personally remit their monies to the cooperative societies".

\section{President A:}

"Cooperators who are on loans are asked to pay back their loans to the cooperative societies but this is not yielding the expected results. There is also the meeting of individual debtors' bank to secure a standing order to get back the loans from source".

\section{Research Question 2}

How do the cooperative societies manage their funds and recover loans during the IPPIS era?

\section{Responses \\ Chairman A:}

"Management committee comprising union EXCOs and cooperative society EXCOs are set up to draw guidelines on how funds are managed".

\section{Chairman B:}

"There is an increase in the assets base of the cooperative society in order to put the cooperative society on a good financial base".

\section{President A:}

"To ensure a communication through the AccountantGeneral office to the IPPIS to remit the deducted funds to the cooperative society".

\section{Research Question 3}

What relationship exists between the unions, cooperative societies and IPPIS office for loans recovery?

\section{Responses \\ Chairman A:}

"There is no clear relationship yet but IPPIS has deducted both union dues and third party deductions without remitting to the unions and the cooperative society".

\section{Chairman B:}

"The IPPIS office has deducted dues of members but have neither remitted to the unions nor the cooperative society".

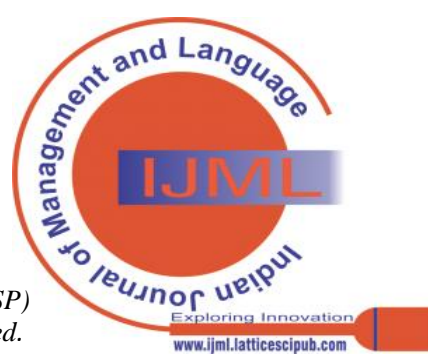




\section{President A:}

"The cooperative society is liaising with the university bursar to get to the IPPIS office to establish a working relationship in order to recover loans from debtors".

\section{DISCUSSION OF FINDINGS} researchers conclude that there is no full proof of internal security measures put in place to recover loans, other than that members and debtors were sensitized to repay their loans, which has not yielded the desired result. This is so because the current researchers are of the opinion that it is only when there is some sort of force or legal binding that these individuals would voluntarily pay back their loans and other dues to the unions and cooperative societies. This finding is in support of the guidelines as outlined by Business Victoria (2019) as one of the several ways of loan recovery.

For Research Question 2, the participants responded that committees are set up in the cooperative societies to manage their funds through several management strategies, while also increasing the financial base of the cooperative societies through diversifying into other ventures that would yield more finances to the societies. The present researchers feel this is because it will keep the unions and cooperative societies still in business even when loans are not fully recovered. This finding is in support of Fortunate (2011), who found out through his study on policy management that recovery procedures (management strategies) are significant in the success of loans recovery.

The responses from participants for Research Question 3 , showed that there is no clearly established relationship between the unions, cooperative societies and the IPPIS office for loans recovery, even when the IPPIS are consistently deducting both union dues and third party deductions such as loans in the cooperative societies. However, plans are underway to liaise with the Bursary of the University to get to the IPPIS through the office of the Accountant-General of the Federation. This is so **because the IPPIS office presents itself as an invisible entity that cannot easily be reached for any transactions with the university. The result of this findings is in total disagreement with the positions of Ikeanyionwu and Ugochukwu (2020), which averred that the IPPIS office was established, among other functions, to deduct and remit third party deductions to federal government establishments among which the university is inclusive.

\section{CONCLUSION}

This study has investigated internal security, management of funds and IPPIS challenges among unions and cooperative societies in tertiary institutions in Nigeria: a focus of the University of Uyo, Uyo. It is rather unfortunate that when the government may have good intentions for its employees, the few privileged individuals who mount vital offices for the government become so power-drunk that policies are defeated at the implementation stages. Now that university staff, through their unions and cooperative societies are facing difficulties in financial transactions, the IPPIS office should wake up to its responsibility of transparency, ingenuity and abide by the tenets of its establishment. This is only when the unions and the cooperative societies would have a hitch-free relationship in
From the responses from Research Question 1, the

all financial dealings with the IPPIS, then peace would return to universities once more.

\section{Recommendations}

Based on the focus of this study, the following recommendations are made:

$>$ The unions and cooperative societies should employ loan recovery agents for loan recovery among members as an internal security measure.

$>$ The unions and the cooperative societies should bring together debtors' banks and guarantors of debtors to a round table agreement on the way forward to recover loans.

$>$ The IPPIS office, through the university bursar, should ensure a smooth working relationship to aid remittance of union dues and third party deductions.

$>$ The IPPIS should also be transparent enough to abide by the laws of its establishment in order not to undermine its functions.

\section{REFERENCES}

1. Abdullahi, S. A. (2001). The development of trade unionism in Nigeria: achievements and Problems. Journal of Business Administration, 1(1): 47-56

2. Asuquo, M. O. (2016). Co-operative Finance \& Management. Uyo: Afahaide \& Bros.

3. Business Victoria (2019). Debt recovering: recover your customers' overdue payments to increase cash flow. State Government of Victoria. Available on www.business.vic.gov.au. Retrieved on July 02, 2020.

4. Effiom, R. A. (2014). Impact of cooperative societies in national development and the Nigerian economy. Global Journal of Social Science, 3: 19-29. [CrossRef]

5. Elesas and Associates (1998). Is relationship lending special? Evidence from credit file data in Germany, working paper 98-105. Centre for Financial Studies, Johnn Wolferg Goethe University, Frankfurt.

6. Etim, P. J. and Egwuasi, P. I. (2007). Preference of discipline in checkmating unionism in a dynamic secondary school system: the experiences of selected schools in Uyo Urban. Benue State University Journal of Education (BSUJE), 8: 118-125.

7. Fortunate, A. (2011). Credit policy management and loan recovery process in the banking sector: a case study of post-bank Uganda (Kabule Branch). A published research report submitted to Makarere University, School of Lifelong Learning and External Studies. Available at www.cees.mak.ac.ug. Retrieved on July 02, 2020.

8. Francis, A. (2010). The concept of debt recovery management. Toulose Business School. Available at www.mbaknol.com. Retrieved on July 01, 2020.

9. Hissom, A. (2009). Introduction to Management Technology BMRT11009 - Section 300. Keit State University.

10. iEduNote (2017). Cooperative society: definition, characteristics, principles, advantages and limitations. Available at http://www.iedunote.com/cooperativesociety. Retrieved on June 15, 2020.

11. Ikeanyionwu, C. and Ugochukwu, W. N. (2020). Unpublished pape on prospects and controversies of integrated personnel and payroll system in Nigeria tertiary institutions. Federal College of Education (Technical) Umunze, Anambra State, Nigeria.

12. Kamar, H. and Ayuma, C. (2016). Effect of debt recovery techniques on performance of selected financial institutions in Eldoret Town. International Journal of Human and Social Science Invention, 5(10): 82-96. Available on www.ijhssi.org. Retrieved on July 03, 2020.

13. Neumann, J. U. and Morgenstern, O. (1944). Theory of Games and Economic Behaviour. Princeton, NJ: Princeton University Press.

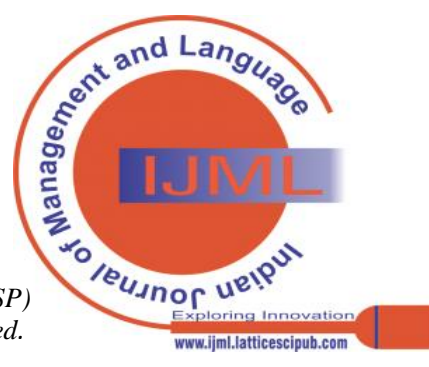


14. Orji, M. G. and Ringim, K. J. (2016). Trade unionism on academic performance and development of Nigerian universities: a comparative study. Journal of World Economic Research, 5(6): 91100. [CrossRef]

15. Smith, A. (1937). The Wealth of Nations. Edited by Edwin Cannan, 1904. New York, NY: Modern Library.

\section{AUTHORS PROFILE}

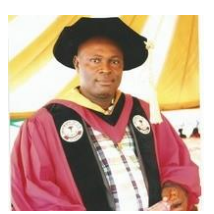

Princewill I. Egwuasi, PhD is of the Department of Curriculum Studies, Educational Management and Planning, University of Uyo, Uyo, Nigeria. He belongs to several professional bodies.

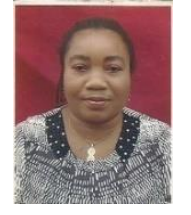

Emem E. Umoren, is of the Department of Curriculum Studies, Educational Management and Planning, University of Uyo, Uyo, Nigeria

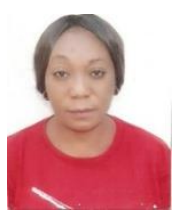

Husseina K. Wakili, is of the Department of Curriculum Studies, Educational Management and Planning, University of Uyo, Uyo, Nigeria.

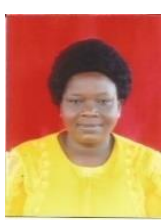

Rebecca J. Akpabio, is of the Department of Curriculum Studies, Educational Management and Planning, University of Uyo, Uyo, Nigeria

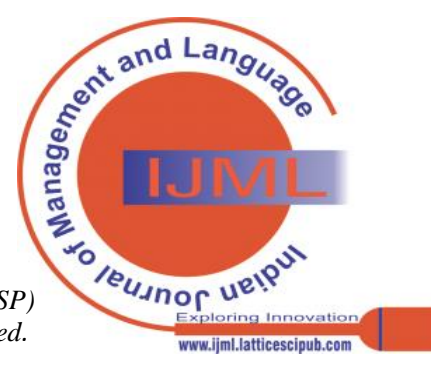

